\title{
A comparison of structure-activity of Cu-modified over different mesoporous silica supports for catalytic conversion of levulinic acid
}

Putrakumar Balla ( $\square$ bputrakumar@yahoo.com )

JiangXi University of Science and Technology https://orcid.org/0000-0001-9013-4595

\section{Seelam Prem Kumar}

Oulun Yliopisto https://orcid.org/0000-0001-9016-9587

\section{Ginjupalli Srinivasarao}

Higher College of Technology Muscat https://orcid.org/0000-0001-8639-1425

\section{Karthikeyan Rajan}

JiangXi University of Science and Technology https://orcid.org/0000-0002-9323-4724

\section{Mitta Harishekar}

IICT CSIR: Indian Institute of Chemical Technology

Keiski Riitta

Oulun Yliopisto https://orcid.org/0000-0003-2753-7062

\section{Tong Xiang Liang}

JiangXi University of Science and Technology

\section{Research Article}

Keywords: Copper, Mesoporous silica, Levulinic acid, $\mathrm{y}$-Valerolactone

Posted Date: March 11th, 2021

DOl: https://doi.org/10.21203/rs.3.rs-248668/v1

License: (9) This work is licensed under a Creative Commons Attribution 4.0 International License. Read Full License 


\section{Abstract}

Catalytic hydrogenation of levulinic acid (LA) to $y$-valerolactone (GVL) was investigated over four different types of mesoporous silica (SBA-15, MCM-48, MCM-41, and KIT-6) supported copper (5 wt.\%) catalysts. The $\mathrm{Cu}$ was incorporated into mesoporous silica supports by a sequential impregnation method. A detailed investigation of the support structure-activity correlation was done and the performance of the catalysts in LA conversion was studied. Detailed characterisation techniques were used to evaluate the physical and catalytic properties of the studied catalysts. The structure type and physicochemical properties of the silica support had a significant effect on the overall performance of the catalysts. Among them, over Cu/SBA-15 catalyst, a complete levulinic acid (LA) conversion with $98 \%$ gamma valerolactone $(G V L)$ selectivity was achieved at $265^{\circ} \mathrm{C}$ under ambient $\mathrm{H}_{2}$ pressure. The superior performance of $\mathrm{Cu} / \mathrm{SBA}-15$ catalyst was due to the high surface acidity, reducibility of $\mathrm{Cu}$ oxides species, and highly dispersed Cu particles over SBA-15 structure. The results confirmed that the activity of the catalysts is significantly affected by the textural properties, surface acidity and copper dispersion. Durability of all the catalysts were tested for $50 \mathrm{~h}$ time on stream and over the SBA-15 catalyst, only a small drop in the activity was observed.

\section{Statement Of Novelty}

In the present work, the novelty and scientific significance lies in introducing the different types mesoporous silica (MS) structures in catalytic hydrogenation of Levulinic acid. We designed and developed a novel and inexpensive catalyst with ultra-fine Cu particles with low and optimal loading over robust mesoporous silica support i.e., SBA-15.

\section{Introduction}

Levulinic acid (LA) has been considered as one of the most versatile and renewable molecules produced mainly from lignocellulosic biomass. It has a great potential in biorefinery applications [1-3]. Due to this, considerable efforts are being made and multiple strategies are being proposed for the efficient conversion of LA to value-added compounds and fuels. Among the various transformations of LA, catalytic hydrogenation of LA to $y$-valerolactone (GVL)is an important route in the valorisation of biomass platform molecules to specialty chemicals $[4,5]$. GVL has been widely used as a sustainable liquid feedstock in the production of transportation fuels and as an additive. Further, GVL acts as a potential monomer in the manufacturing of different kinds of plastics and it can be directly utilized as a green solvent [6]. Moreover, GVL has been used as a hydrogen carrier in the fuel cell applications and also used as a $20 \%$ biofuel (produced from GVL) balanced with conventional fuel in the biofuel engine and used in the production of non-enzymatic sugars from biomass.

Catalytic hydrogenation of LA to GVL were studied over a wide variety of noble ( $\mathrm{Ru}, \mathrm{Pt}, \mathrm{Pd}, \mathrm{Au}$, and Ir) [711], non-noble ( $\mathrm{Cu}, \mathrm{Ni}$, and $\mathrm{Co}$ ) [12-14] and bimetallic (RuNi, RuSn,CuFe and CuNi) [15-18] catalysts in both continuous and batch reactor systems under various reaction conditions. Among the catalysts 
reported, ruthenium $(\mathrm{Ru})$ based catalytic systems are considered to be the most active and selective in the conversion of LA to GVL in both i.e., homogenous and heterogeneous media [17]. Many reports are focused on non-noble based base metal catalysts due to their cost and abdundance. Developing $\mathrm{Cu}$ based catalysts is more appropriate and industrially viable for the future biorefinery applications. The copper based catalysts are considered to be promising alternatives to the noble metal catalysts, which have shown moderately high performance in the catalytic transformation of LA to GVL. For instance, Upare et al. reported over $5 \mathrm{wt} . \% \mathrm{Cu} / \mathrm{SiO}_{2}$ catalyst exhibited a complete conversion of LA with $94 \% \mathrm{GVL}$ selectivity and $6 \%$ angelica lactone (AL) at $265^{\circ} \mathrm{C}$ and $0.1 \mathrm{MPa}$ [19]. Lomate et al. 2017 studied the effect of $\mathrm{Cu}$ modified $\mathrm{SiO}_{2}$ support with different textural properties of $\mathrm{SiO}_{2}$ and exhibited varied activities in vapor phase hydrogenation of levulinic acid. They found no correlation between activities and selectivity with support acidity, but strong Cu-support interactions due to partially oxidised $\mathrm{Cu}$ species was the main reason for the high activity [20]. Moreover, Rei et al., used a $20 \mathrm{wt} . \% \mathrm{Cu} / \mathrm{SiO}_{2}$ catalyst, and achieved $73.4 \%$ LA conversion with $75.4 \% \mathrm{GVL}$ selectivity at $250^{\circ} \mathrm{C}$ and WHSV of $3.30 \mathrm{~h}^{-1}$ [21]. Recently, Sun et al. studied three different non-noble metal catalysts i.e., $\mathrm{Co}, \mathrm{Ni}$, and $\mathrm{Cu}$ based alumina catalysts. Overall, $\mathrm{Cu} / \mathrm{Al}_{2} \mathrm{O}_{3}$ is the most selective catalyst due to the high surface acidity and $\mathrm{Cu}$ dispersion [22]. Furthermore, in another study, $\mathrm{Cu} / \mathrm{Al}_{2} \mathrm{O}_{3}$ and $\mathrm{Cu} / \mathrm{ZrO}_{2}$ catalysts were reported in the hydrogenation of $\mathrm{LA}$ in a fixed bed reactor at $265^{\circ} \mathrm{C}$ under ambient pressure and over $\mathrm{Cu} / \mathrm{Al}_{2} \mathrm{O}_{3}$, highest catalytic activity in terms of $\mathrm{GVL}$ selectivity and LA conversion was gained [23, 24]. In most of the studies, the GVL selectivity was directly correlated to the active metal surface area, surface acidity, and the metal dispersion. Henceforth, designing and developing a highly dispersed, low cost, and abundant Cu-based catalyst in combination with a robust support was the aim of thiswork in LA hydrogenation.

Generally, mesoporous silica supports (SBA-15, MCM-41, MCM-48, and KIT-6) possess high specific surface areas, ordered pore structures, and high thermal stability, which makes them ideal materials for many catalytic reactions. High surface area mesoporous silica (MS) supports can efficiently provide the maximum active sites per mass of catalyst. Moreover, MS supports avoid the diffusion limitations for the reactants and products due to their unique textural properties. However, changing the textural and surface properties of different mesoporous materials can lead to varied catalytic performances[25].

This research work aim is to study the Cu loaded mesoporous silica supported catalysts with different textural properties in a fixed bed reactor atambient pressure. Thus, this work gives an overall correlation between the role of MS textural properties, metal-support interaction, copper dispersion withthe catalytic activity. In the present work, four different types of mesoporous silica supports were synthesized by a hydrothermal method and then copper nanoparticles were deposited by a wet impregnation method. The catalysts characterized by using various analysis techniques and methods such as microscopic, spectroscopic, XRD, UV-DRS, $\mathrm{N}_{2}$ sorption measurements, SEM, TEM, $\mathrm{H}_{2}-\mathrm{TPR}$, and $\mathrm{NH}_{3}$-TPD. Active surface area and dispersion of copper were calculated from the $\mathrm{N}_{2} \mathrm{O}$ titration method. Catalytic activities were determined in terms of LA conversion, GVL selectivity and catalysts stability.

\section{Experimental}




\section{Materials and methods}

The parent silica materials (SBA-15, MCM-41, MCM-48, and KIT-6) were synthesized from the study [26]. In the synthesis of SBA-15, $4 \mathrm{~g}$ of P123 (Poly(ethylene glycol)-block-poly(propylene glycol)-blockpoly(ethylene glycol) polymer and $9.44 \mathrm{~g}$ of $\mathrm{KCl}$ were dissolved in $2 \mathrm{M} \mathrm{HCl}$ solution $(\sim 90 \mathrm{~g})$. The final solution was stirred for $2 \mathrm{~h}$ at $35^{\circ} \mathrm{C}$ until homogeneously mixed. In the next step, $6.44 \mathrm{~g}$ of TEOS (Tetraethyl orthosilicate) was added dropwise under continuously stirring for $2 \mathrm{~h}$. The complete mixture was then transferred to a sealed Teflon lined container and kept at $100^{\circ} \mathrm{C}$ for $24 \mathrm{~h}$ under static conditions. The resulting precipitate was filtered and washed with deionised water $(\mathrm{pH} 6.9 \pm 0.2)$ until pH $7.0 \pm 0.2$ was attained. Further, it was dried for $12 \mathrm{~h}$ at $80^{\circ} \mathrm{C}$ and followed by calcination at $500^{\circ} \mathrm{C}$ for $6 \mathrm{~h}$ under air.

For MCM-48, $2.4 \mathrm{~g}$ of CTAB (Cetyltrimethylammonium bromide) was mixed with $50 \mathrm{~mL}$ of deionized water, $50 \mathrm{~mL}$ of $\mathrm{C}_{2} \mathrm{H}_{5} \mathrm{OH}$ and $12 \mathrm{~mL}$ of $\mathrm{NH}_{3}$ (32 vol.\%). This mixture was stirred until a clear solution was obtained. In the next step, TEOS $(3.4 \mathrm{~g})$ wasadded to the mixture and stirred for $2 \mathrm{~h}$. The final product was filtered, extensively washed, dried overnight, and calcined for $6 \mathrm{~h}$ at $600^{\circ} \mathrm{C}$.

MCM-41 was prepared by using $2.4 \mathrm{~g}$ of CTAB dissolved in $120 \mathrm{~mL}$ of deionized water and then stirred until a clear solution was visible. After dissolution, $8 \mathrm{~mL}$ of $\mathrm{NH}_{3}(32 \%)$ was added to the solution, followed by dropwise addition of $10 \mathrm{~mL}$ of TEOS and stirring at $35^{\circ} \mathrm{C}$ for $24 \mathrm{~h}$. The final product was washed with ethanol $/ \mathrm{H}_{2} \mathrm{O}$, dried for $12 \mathrm{~h}$ at $60^{\circ} \mathrm{C}$ and calcined for $5 \mathrm{~h}$ at $500^{\circ} \mathrm{C}$.

For synthesis of KIT-6, Pluronic P123 (6 g) was dissolved in $215 \mathrm{~mL}$ of deionized water and $11.8 \mathrm{~g}$ of $\mathrm{HCl}$ $(35 \% \mathrm{v} / \mathrm{v})$ solution under stirring. After dissolution, a $6 \mathrm{~g}$ of $\mathrm{n}$-butanol was added dropwise under continuous stirring. Next, a TEOS $(12.9 \mathrm{~g})$ was added and stirred at $35^{\circ} \mathrm{C}$ for $24 \mathrm{~h}$. The final solution was transferred into a sealed Teflon container and subjected to hydrothermal treatment at $100^{\circ} \mathrm{C}$ for one day. The final solid product was washed, filtered, and dried overnight and next calcined at $500^{\circ} \mathrm{C}$ for $5 \mathrm{~h}$.

The supported copper catalysts with $5 \mathrm{wt}$.\% Cu loading was prepared by a wetness impregnation method. In the typical synthesis procedure, $1.0 \mathrm{~g}$ of mesoporous silica support (SBA-15, MCM-41, MCM-48, and KIT-6) was dispersed in $20 \mathrm{~mL}$ of aqueous copper nitrate solution and stirred at $60^{\circ} \mathrm{C}$. The samples were dried overnight and calcined at $500^{\circ} \mathrm{C}$ for $5 \mathrm{~h}$. The prepared catalysts were labeled as Cu/SBA-15, $\mathrm{Cu} / \mathrm{MCM}-41, \mathrm{Cu} / \mathrm{MCM}-48$ and $\mathrm{Cu} / \mathrm{KIT}-6$.

\section{Catalyst Characterisation}

X-ray diffraction patterns were obtained by a D8 X-ray diffractometer (Bruker, Germany) using Cu Ka radiation (-1.5406 $\mathrm{A}^{\circ}, 40 \mathrm{kV}$ and $\left.30 \mathrm{~mA}\right)$. Nitrogen sorption measurements were conducted on an Autosorb-1 analyzer (Quanta chrome) at $-196^{\circ} \mathrm{C}$. Before analysis, the samples were degassed at $250^{\circ} \mathrm{C}$ for $6 \mathrm{~h}$ under vacuum. The specific surface area and pore size distribution were measured by using Brunauer-Emmett-Teller (BET) and Barret-Joyner-Halenda (BJH) methods, respectively. The UV-Vis diffused reflectance spectra (UV-DRS) were recorded by a UV-visible spectrometer (GBC scientific-Cintra). Transmission electron microscopy (TEM) images were captured on a Hitachi HT7700 operated at $100 \mathrm{kV}$ 
instrument. Scanning electron microscopy (SEM) images were taken on a Philips/Fei Quanta 200F SEM operated at $20 \mathrm{kV}$ instrument.

Hydrogen temperature programmed reduction $\left(\mathrm{H}_{2}\right.$-TPR) and temperature programmed desorption of $\mathrm{NH}_{3}$ ( $\mathrm{NH}_{3}$-TPD) were conducted on micrometric instruments (Auto Chem. 2910). In $\mathrm{H}_{2}$-TPRexperiment, $0.1 \mathrm{~g}$ of sample was pretreated by passing $\mathrm{He}$ gas at $200^{\circ} \mathrm{C}$ for $2 \mathrm{~h}$ and then cooled down to ambient temperature. TPR analysis was performed from $25^{\circ} \mathrm{C}$ to $600^{\circ} \mathrm{C}$ in a flow of $5 \% \mathrm{H}_{2} /$ Ar with a ramping rate $10^{\circ} \mathrm{C} / \mathrm{min}$. Moreover, in TPD- $\mathrm{NH}_{3}$ experiment, $0.1 \mathrm{~g}$ sample was pretreated by a flow of He gas at $200^{\circ} \mathrm{C}$ for $2 \mathrm{~h}$ followed by saturation with $10 \% \mathrm{NH}_{3} / \mathrm{He}$ gas at $80^{\circ} \mathrm{C}$ for $1 \mathrm{~h}$. It was then purged with He gas at $140^{\circ} \mathrm{C}$ for $2 \mathrm{~h}$. TPD analysis was carried out from $25^{\circ} \mathrm{C}$ to $600^{\circ} \mathrm{C}$ at a ramping rate of $10^{\circ} \mathrm{C} / \mathrm{min}$. Grams $/ 32$ software was used to calculate the amount of $\mathrm{H}_{2}$ consumed and desorbed $\mathrm{NH}_{3}$ values.

$\mathrm{N}_{2} \mathrm{O}$ decomposition experiments were also conducted on micrometric instruments (Auto Chem. 2910). Prior to analysis, the sample was reduced with $\mathrm{H}_{2}$ gas at $300^{\circ} \mathrm{C}$ for $3 \mathrm{~h}$ followed by He purges for 30 min and then cooled to $80^{\circ} \mathrm{C}$. Thereafter, the sample was exposed to $2 \% \mathrm{~N}_{2} \mathrm{O}-\mathrm{He}$ for $30 \mathrm{~min}$ to oxidize $\mathrm{Cu}$ to $\mathrm{Cu}_{2} \mathrm{O}$. Reduction of surface copper oxide was performed by a similar procedure to TPR experiments. $\mathrm{Cu}$ surface area, dispersion and crystal size were measured from the total amount of $\mathrm{H}_{2}$ consumed during the TPR analysis. Copper metal surface area of the catalyst were determined by the following equation.

\section{$\mathrm{S}_{\mathrm{cu}}=\mathrm{N}_{\mathrm{M}} \cdot \mathrm{N}_{\mathrm{A}} \cdot \mathrm{SF} / \mathrm{Ns}$}

where $S_{c u}$ is the Metal surface area $\left(\mathrm{m}^{2} \mathrm{~g}^{-1}\right), \mathbf{N}_{\mathrm{M}}$ is the Gas adsorbed at monolayer, $\mathbf{N}_{\mathrm{A}}$ is the Avogadro number, $\mathbf{S F}$ is the Adsorption stoichiometry, and $\mathbf{N s}$ is the Number of surface copper atoms per unit area $\left(1.47 \times 10^{19} \mathrm{~m}^{-2}\right)$.

By assuming copper metal to bespherical crystallites, the particle size can be calculated from following equation: Particle size $\left(A^{\circ}\right)=6 \cdot 10^{4} /\left(S_{\mathrm{Cu}} \cdot \boldsymbol{P}_{\mathrm{Cu}}\right)$

where $\boldsymbol{\rho}_{\mathrm{Cu}}$ is the copper density $\left(8.92 \mathrm{gcm}^{-3}\right)$.

\section{Catalytic activity}

The catalytic hydrogenation of LA was performed in afixed-bed glass reactor with $9 \mathrm{~mm}$ inner diameter and $32 \mathrm{~cm}$ in length over a temperature range from 225 to $300^{\circ} \mathrm{C}$ at $0.1 \mathrm{MPa}$ hydrogen pressure. The catalyst $(0.3 \mathrm{~g})$ was mixed with glass beads and loaded at the center of the reactor with glass wool packed from both ends. Beforethe catalytic activity test, the catalyst was pretreated with $\mathrm{H}_{2}$ stream at $350^{\circ} \mathrm{C}$ for $3 \mathrm{~h}$. After reduction, the reactor temperature was cool down to $265^{\circ} \mathrm{C}$ and a stream of aqueous solution (10 wt.\%) of LA was fed into the reactor along with $\mathrm{H}_{2}$ at WHSV $0.550 \mathrm{~h}^{-1}$. The reaction products were collected after every hour in an ice trap and later analyzed by GC-MS (HP5973-GC-MSD) by using capillary column (HP-1MS). 


\section{Results And Discussion}

Low angle XRD patterns of four pure supports (SBA-15, MCM-41, MCM-48, and KIT-6) and their respective Cu impregnated samples have been presented in Figure. 1a and inset in Fig. 1a, respectively.The lowangle diffraction patterns of SBA-15 and Cu/SBA-15 exhibited well-resolved diffraction peaks at around $2 q-0.9^{\circ}$ corresponds to $\left(\begin{array}{lll}1 & 0 & 0\end{array}\right)$ reflection of SBA-15 [27] and indicating a hexagonal unit cell. The results confirmed that the mesoporous silica structure was well intact after the copper incorporation. However, the impregnation of copper on the silica support resulted in a low intensity peak, which could be ascribed to the scattering phenomenon of metallic copper nanoparticles. The XRD pattern of pure MCM- 41 (inset in Fig.1a) shows three wall-separated reflections at $2 \mathrm{q}-3.7^{\circ}$ (a strong intense peak), around $2 \mathrm{q}-4.5^{\circ}$ and $2 q-4.7^{\circ}$, denoted as weak intense peaks, corresponding to $d_{100}, d_{110}$ and $d_{200}$ planes, respectively, which was considered as the fingerprints of ordered mesoporous structure [28] of MCM-41 materials. After impregnation of copper over the MCM-41 support, the intensity of all XRD peaks decreased considerably due to occupied Cu species in the cylindrical mesopores of the MCM-41 support. The diffraction peaks of MCM-48 and Cu/MCM-48 were found in well agreement with the unique 3D cubic structures of MCM-48 as reported elsewhere [29]. Moreover, KIT-6 sample exhibited well-resolved reflections, which were assigned to a well-ordered 3-D cubic la3d symmetry of silica structure [30]. Further, the 5Cu/KIT-6 sample manifested a cubic structure, which was very similar to its parent sample. All Cu impregnated mesoporous samples exhibited a steady declined in their diffraction peak intensities as compared to their respective parent samples.

\section{Table 1. Textural properties of different mesoporous silica support and the Cu modified catalysts.}

\begin{tabular}{ccccc}
\hline Catalyst & $\begin{array}{c}\text { Copper loading } \\
\text { (wt. } \\
\text { \%) }\end{array}$ & $\begin{array}{c}\text { BET surface area }^{\mathrm{b}} \\
\left(\mathrm{m}^{2} / \mathrm{gm}\right)\end{array}$ & $\begin{array}{c}\text { Pore volume }^{\mathrm{b}} \\
(\mathrm{cc} / \mathrm{gm})\end{array}$ & $\begin{array}{c}\text { Average }^{\mathrm{p}} \\
\text { pore diameter }^{\mathrm{b}} \\
\text { (nm) }\end{array}$ \\
\hline SBA-15 & - & 1062 & 1.413 & 5.10 \\
MCM-41 & - & 759 & 0.692 & 3.65 \\
MCM-48 & - & 1125 & 0.6075 & 2.16 \\
KIT-6 & - & 767 & 0.8969 & 4.67 \\
Cu/SBA-15 & 4.61 & 764 & 0.9137 & 4.78 \\
Cu/MCM-41 & 4.48 & 693 & 0.5971 & 2.67 \\
Cu/MCM-48 & 4.51 & 928 & 0.5669 & 2.06 \\
Cu/KIT-6 & 4.57 & 524 & 0.7567 & 5.77 \\
\hline
\end{tabular}

a-Results obtained from ICP

b-Results obtained from $\mathrm{N}_{2}$ sorption measurements

The wide-angle XRD patterns of the supported copper samples have been illustrated in Fig.1b. All the XRD patterns shown broad peaks between $2 \mathrm{q}=15-30^{\circ}$, which were considered as characteristic peaks of amorphous silica. Further, Cu/KIT-6 shown distinguished peaks correspond to CuO (JCPDS 45-0937) at $2 q=32.63^{\circ}, 35.54^{\circ}, 38.85^{\circ}, 48.95^{\circ}, 53.61^{\circ}, 58.54^{\circ}$, and $61.73^{\circ}$, respectively. The observed peaks indicated the presence of bulk CuO in KIT-6, however, similar peaks were absent in $\mathrm{Cu} / \mathrm{SBA}-15, \mathrm{Cu} / \mathrm{MCM}-41$ and $\mathrm{Cu} / \mathrm{MCM}-48$ catalysts. The results suggested that $\mathrm{CuO}$ crystallites were highly dispersed over $\mathrm{Cu} / \mathrm{SBA}-15$, 
Cu/MCM-41 and Cu/MCM-48 catalysts and formed small Cu crystallites $(<4 \mathrm{~nm})$ over the respective supports.

Moreover, $\mathrm{N}_{2}$ adsorption-desorption analysis was carried out to determine the specific surface area, cumulative pore volume and average pore size of the prepared catalysts. $\mathrm{N}_{2}$ sorption isotherms and the respective BJH pore size distribution profiles of pure supports and supported copper catalysts have been presentedin Fig. 2a and Fig. 2b. For all four support catalysts, a sharp enhancement in the adsorbed and desorbed isotherms were displayed in the relative pressure range of 0.6-0.7 for SBA-15, 0.3-0.35 for MCM41, 0.25-0.35 for MCM-48 and 0.5-0.8 for KIT-6 [31, 32]. The isotherms of pure SBA-15 and Cu/SBA-15 exhibited a sharp uptake of $\mathrm{N}_{2}$ at relative pressures of $0.6-0.8$ showing type IV isotherm with $\mathrm{H} 1$ hysteresis loop. This indicated the presence of evenly distributed cylindrical narrow pores. The isotherms of pure MCM-41 support and Cu/MCM-41 exhibited typical type IV isotherm with definite elevation in $\mathrm{P} / \mathrm{P}_{\mathrm{o}}$ range of $0.25-0.35$ and $0.3-0.4$ due to capillary condensation and spontaneous filling of mesopores, respectively. The isotherm of MCM-48 presented a sharp adsorption atrelative pressure of about 0.25 , representing narrow distribution of pores. The specific surface area, pore volume and average pore diameter declined significantly for supported catalysts i.e. Cu/SBA-15, Cu/MCM-41 and Cu/MCM-48 catalysts compared to pure support materials (Table1). The incorporation of copper into mesopores resulted in increased density of $\mathrm{Cu}$ sites and thus, a considerable decrease in the surface area of supporting material was observed. However, in the case of $\mathrm{Cu} / \mathrm{KIT}-6$, the average pore diameter was slightly increased which ascribed the blocking of the small pores [26].

The UV-DRS spectra for all the supported catalysts have been presented in Fig.3. All the catalysts exhibited one common intense absorption band ranging from 200 to $280 \mathrm{~nm}$, which could be originated from the charge transfer transition between ligand $\mathrm{O}^{2-}$ and $\mathrm{Cu}^{2+}$ in an isolated state [33]. Further, a slight shoulder peak was also observed for the Cu/SBA-15, Cu/MCM-48 and Cu/KIT-6 catalysts at around 300 $\mathrm{nm}$, indicating the limited presence of oligomeric cluster-like moieties originating from the charge transfer between $\mathrm{Cu}^{2+}$ and $\mathrm{O}^{2-}$ in the $(\mathrm{Cu}-\mathrm{O}-\mathrm{Cu})_{n}$ surface species [34]. The charge transfer band of $\mathrm{Cu} / \mathrm{MCM}$ 48 was found to be more intense and broader compared to other catalysts indicating the formation of mononuclear oxide species in a dispersed state. The broad absorption band with weak intense band was observed between $500-800 \mathrm{~nm}$, and this band was assigned to electron $\mathrm{d}-\mathrm{d}$ transitions in $\mathrm{Cu}_{2 \mathrm{p}}$ in a octahedral surrounding by the oxygen in $\mathrm{CuO}$ particles [35].

The TPR profiles and their respective hydrogen consumption values of the supported copper catalysts have been presented in Fig. 4 and Table 2 respectively. From Fig. 4, herein, two similar reduction peaks at $\sim 220^{\circ} \mathrm{C}$ and $\sim 290^{\circ} \mathrm{C}$ were observed for Cu/SBA-15 and Cu/MCM-48 catalysts, respectively. The low temperature peak was corresponding to a finely dispersed reduced $\mathrm{CuO}$ to $\mathrm{Cu}$, while the high temperature peak was originated from the reduction of bulk $\mathrm{CuO}$ species presented in the mesoporous silica supports.

The published reports related to the reducibility of supported copper catalysts have suggested that bulk $\mathrm{CuO}$ is hard to reduce as compared to the highly dispersed copper oxides [36]. In many studies, similar peaks at $\sim 220^{\circ} \mathrm{C}$ and $\sim 290^{\circ} \mathrm{C}$ in $\mathrm{Cu} / \mathrm{MCM}-48$ corresponds to widely dispersed over support surface and 
the bulk $\mathrm{CuO}$ species presented inside the structure, respectively. The TPR profiles for the $\mathrm{Cu} / \mathrm{MCM}-41$ and $\mathrm{Cu} / \mathrm{KIT}-6$ consisted a single reduction peak in high temperature region (around $310^{\circ} \mathrm{C}$ ). The profile for $\mathrm{Cu} / \mathrm{MCM}-41$ corresponds to the reduction of bulk $\mathrm{CuO}$ to metallic copper, while the reduction profile of $\mathrm{Cu} / \mathrm{KIT}-6$ suggested the shifting of peak towards higher temperature region due to the existence of copper oxides in the bulk form. Typically, $\mathrm{H}_{2}$ consumption of $\mathrm{Cu} / \mathrm{MCM}-48$ in a low temperature region was found to be relatively high compared to all other catalysts. Thus, indicates that the most of $\mathrm{CuO}$ species were highly dispersed over the MCM-48 and SBA-15 supports and that could be easily reduced. The results were found to be in well agreement with the XRD, UVDRS, and textural properties.

Table 2. The maximum peak temperature $\left(\mathrm{T}_{\max }\right)$ and $\mathrm{H}_{2}$ consumption values of various copper catalysts from TPR analysis and desorbed $\mathrm{NH}_{3}$ values from TPD results.

\begin{tabular}{ccccccc}
\hline Catalyst & $\begin{array}{c}\mathrm{T} \\
\max ^{1} \\
\left({ }^{0} \mathrm{C}\right)\end{array}$ & $\begin{array}{c}\mathrm{H}_{2} \text { Consumption } \\
(\mathrm{mmol} / \mathrm{gm})\end{array}$ & $\begin{array}{c}\mathrm{T} \\
\mathrm{max}^{2} \\
\left({ }^{0} \mathrm{C}\right)\end{array}$ & $\begin{array}{c}\mathrm{H}_{2} \text { Consumption }^{\mathrm{a}} \\
(\mathrm{mmol} / \mathrm{gm})\end{array}$ & $\begin{array}{c}\text { Total } \\
\mathrm{H}_{2} \text { Consumption } \\
(\mathrm{mmol} / \mathrm{gm})\end{array}$ & $\begin{array}{c}\text { Total } \\
\text { desorbed } \\
\mathrm{NH}_{3} \\
(\mathrm{mmol} / \mathrm{gm})\end{array}$ \\
\hline $\begin{array}{c}5 \mathrm{Cu} / \mathrm{SBA}- \\
15\end{array}$ & 220 & 96 & 290 & 456 & 552 & 837 \\
$\begin{array}{c}5 \mathrm{Cu} / \mathrm{MCM}- \\
41\end{array}$ & - & - & 301 & 482 & 482 & 564 \\
$\begin{array}{c}5 \mathrm{Cu} / \mathrm{MCM}- \\
48\end{array}$ & 200 & 487 & 279 & 36 & 523 & 671 \\
$5 \mathrm{Cu} / \mathrm{KIT}-6$ & - & - & 318 & 543 & 543 & 441 \\
\hline
\end{tabular}

a-Results from $\mathrm{H}_{2}$-TPR

b-Results obtained from $\mathrm{NH}_{3}$-TPD

The TPD profiles of supported copper catalysts have been shown in Fig. 5 and corresponding data have been summarised in Table 2. All the four catalysts showed one desorption peak below $120^{\circ} \mathrm{C}$ that is due to the physisorbed $\mathrm{NH}_{3}$ over the surface of the catalyst. The $\mathrm{Cu} / \mathrm{SBA}-15$ and $\mathrm{Cu} / \mathrm{MCM}-48$ shown a shoulder peak in between $120-300^{\circ} \mathrm{C}$ which was attributed to the desorption of ammonia from the weak acid sites [37]. All the catalysts exhibited broad desorption peaks at higher temperature (i.e., above $300^{\circ} \mathrm{C}$ ) due to the existence of moderate acid sites on the surface. Further, the total surface acidity of the supported mesoporous silica catalysts was found to be in sequence of $\mathrm{Cu} / \mathrm{SBA}-15>\mathrm{Cu} / \mathrm{MCM}-48>$ Cu/MCM-41> Cu/KIT-6 (Table 2).

Copper dispersion has been defined as the ratio of the number of copper atoms present over the surface to the total number of copper atoms. The copper dispersion, active metal surface area and crystallitesize of copper supported silica catalysts reported in Table 3. According to the $\mathrm{N}_{2} \mathrm{O}$ decomposition results, the $\mathrm{H}_{2}$ uptake, dispersion, and metal area of the mesoporous silica-supported copper catalysts presented was in the decreasing order: $\mathrm{Cu} / \mathrm{MCM}-48>\mathrm{Cu} / \mathrm{SBA}-15>\mathrm{Cu} / \mathrm{MCM}-41>\mathrm{Cu} / \mathrm{KIT}-6$. It was observed that the $\mathrm{Cu} / \mathrm{MCM}-48$ catalyst exhibited highest copper surface area and better dispersion compared to other catalysts (Table 3 ). The reason for this might be the presence of high number dispersed copper sites over MCM-48 surface. 
Table 3. Copper dispersion, metal surface area and particle size of different copper supported on mesoporous silica catalysts.

\begin{tabular}{ccccc}
\hline Catalyst & $\mathrm{H}_{2}$ Uptake $(\mathrm{mmol} / \mathrm{gm})$ & $\begin{array}{c}\text { Dispersion } \\
(\%)\end{array}$ & $\begin{array}{c}\text { Metal area } \\
\left(\mathrm{m}^{2} / \mathrm{gm}_{\mathrm{Cu}}\right)\end{array}$ & Average Particle size (nm) \\
\hline $\mathrm{Cu} /$ SBA-15 & 132 & 34 & 217 & 3.1 \\
$\mathrm{Cu} / \mathrm{MCM}-41$ & 80 & 21 & 132 & 5.1 \\
$\mathrm{Cu} / \mathrm{MCM}-48$ & 151 & 39 & 249 & 2.7 \\
$\mathrm{Cu} /$ KIT-6 & 61 & 16 & 101 & 6.7 \\
\hline
\end{tabular}

The SEM (Fig. 6) and TEM (Fig. 7) analysis were conducted to determinethe morphologies (shape and size of the pore) of the mesoporous silica-supported copper catalysts. SEM image of SBA-15 displayed multiple rope like domains of relatively uniform in size. MCM-48 comprised of the spherical particles with diameter ranging from 0.3 to $0.5 \mu \mathrm{m}$ while pure KIT- 6 support exhibited spherical platelets like morphology. The TEM images of catalysts exhibited a well-defined ordered structure with different sizes. It was noticed that the mesoporous framework of the four samples retained their morphology even after impregnation with copper particles.

\section{Catalytic activity results}

Evaluationof the catalytic activity of mesoporous silica-supported copper catalysts was conducted in a continuous fixed-bed reactor at $265^{\circ} \mathrm{C}$ and $0.1 \mathrm{MPa}$ hydrogen pressure (Table 4). In LA hydrogenation, GVL was found to be the primary and desired product, while angelicalactone (AL) and valeric acid (VA) were produced as the by-products. It was clearly evidentthat the, first LA was dehydrated to $A L$ and then hydrogenated to $\mathrm{GVL}$ in the final stage. According to previous reports, over $5 \mathrm{wt} . \% \mathrm{Cu} / \mathrm{SiO}_{2}$ shown complete conversion of LA with selectivity to GVL of $94 \%$ and $A L$ of $6 \%$ at $265^{\circ} \mathrm{C}$ and $0.1 \mathrm{MPa}$ was obtained. Further, in another study, $20 \mathrm{wt} . \% \mathrm{Cu} / \mathrm{SiO}_{2}$ catalyst has shown $73.4 \% \mathrm{LA}$ conversion and $75.4 \%$ GVL selectivity at $250^{\circ} \mathrm{C}$ and WHSV of $3.30 \mathrm{~h}^{-1}$ [21]. In the present study, we achieved better results with lower Cu loading compared to published data on Cu-based catalysts and overall, 5 wt.\% Cu/SBA-15 exhibited complete conversion of $\mathrm{LA}$ and $98 \%$ selectivity to $\mathrm{GVL}$ at $265^{\circ} \mathrm{C}$ temperature and $0.1 \mathrm{MPa}$ hydrogen pressure. Moreover, $\mathrm{Cu} / \mathrm{MCM}-48$ possessed high active surface area, $\mathrm{Cu}$ dispersion and smaller metallic $\mathrm{Cu}$ particle sizes compared to $\mathrm{Cu} / \mathrm{SBA}-15$, Cu/MCM-41, and Cu/KIT-6. In addition, Cu/MCM-48 showed higher metal surface area however, a lower catalytic activity was exhibited compared to Cu/SBA15. This indicated that in case of $\mathrm{Cu} / \mathrm{MCM}-48$, a low surface acidity and also narrow pores could not render LA to the pore channels and led to low accessibility to the active sites compared to Cu/SBA-15. The conversion of LA over supported mesoporous silica catalyst was in the sequence of Cu/SBA$15>\mathrm{Cu} / \mathrm{MCM}-48>\mathrm{Cu} / \mathrm{MCM}-41>\mathrm{Cu} / \mathrm{KIT}-6$. The order of the LA conversion was observed to be consistent with that of the total surface acidity, thus, exhibiting highest LA conversion for Cu/SBA-15 catalyst. The superior catalytic activity was attributed to the execess availability of the reducible copper species in the 
mesoporous channels of the catalysts. Among all catalysts, 5 wt.\% Cu/SBA-15 achieved superior performance and displayed complete LA conversion with $98 \% \mathrm{GVL}$ selectivity.

Table 4.Catalytic performance of differentmesoporous silica supported Cu catalysts.

\begin{tabular}{cccccc}
\hline Catalyst & Conversion & \multicolumn{4}{c}{ Selectivity (\%) } \\
\cline { 3 - 6 } & $(\%)$ & AL & GVL & VA & Others \\
\hline Cu/SBA-15 & 100 & - & 98 & 2 & - \\
Cu/MCM-41 & 85 & 16 & 77 & 3 & 4 \\
Cu/MCM-48 & 92 & 4 & 92 & 2 & 2 \\
Cu/KIT-6 & 78 & 29 & 69 & 1 & 1 \\
\hline
\end{tabular}

Reaction conditions: 10wt.\% of aqueous levulinic acid,0.3 g catalyst, WHSV0.550 $\mathrm{h}^{-1}$ and $\mathrm{H}_{2}$ flow $30 \mathrm{~mL} \min ^{-1}$ under atmospheric pressure. $\mathrm{VA}=$ valeric acid and $\mathrm{AL}=$ angelica lactone

Hydrogenation of LA over Cu/SBA-15, Cu/MCM-41, Cu/MCM-48 and Cu/KIT-6 was carried out at different reaction temperatures ranging from $225^{\circ} \mathrm{C}$ to $300^{\circ} \mathrm{C}$ (Fig.8). Conversion of LA over the Cu/SBA-15, $\mathrm{Cu} / \mathrm{MCM}-41, \mathrm{Cu} / \mathrm{MCM}-48$ and $\mathrm{Cu} / \mathrm{KIT}-6$ catalysts increased from $77 \%$ to $100 \%, 58 \%$ to $98 \%, 64 \%$ to $100 \%$ and 48 to $88 \%$, respectively, with increasing reaction temperatures from $225^{\circ} \mathrm{C}$ to $300^{\circ} \mathrm{C}$. The conversion attained $100 \%$ at temperatures above $265^{\circ} \mathrm{C}$, while selectivity to $\mathrm{GVL}$ achieved maximum at $265^{\circ} \mathrm{C}$. However, the selectivity for $\mathrm{AL}$ attained very low at similar temperatures. $\mathrm{Cu} / \mathrm{SBA}-15$ and $\mathrm{Cu} / \mathrm{MCM}-48$ show higher than $90 \%$ GVL selectivity with complete LA conversion, whereas Cu/KIT-6 show low catalytic activity in LA conversion and GVL selectivity. Moreover, the selectivity to GVL decreased and selectivity to VA increased with the temperature (from 265 to $300^{\circ} \mathrm{C}$ ). This trend indicated that higher temperatures $\left(300^{\circ} \mathrm{C}\right)$ led to the accelerated reaction and converted GVL into VA. Previous reports concluded similar behavior for the $\mathrm{Cu} / \mathrm{Al}_{2} \mathrm{O}_{3}$ catalyst, which accelerated the dehydration of LA molecules on its surface at high temperatures resulting in the ring opening of GVL and thus, decreased the selectivity towards GVL. Apparently, LA is converted to AL at first followed by its subsequent hydrogenation to GVL. Under the studied reaction conditions, the optimum reaction temperature for converting LA to GVL was $265^{\circ} \mathrm{C}$. There are many copper-based catalytic systems reported in the literature with different $\mathrm{Cu}$ loadings over the various support materialsand reaction conditions. It is hard to compare all of them with our study due to variation in composition, and operating conditions. However, we collected few relevant data which had similar conditions to this work were summarised in Table 5 and short comparison between the reported Cu-based catalysts with this work was made. Recently, complete LA conversion can be achieved at mild temperature, i.e., below $150^{\circ}$ but at high operating pressures [38]. It was an evident that the trade-off factor between operating temperature and pressure in the LA hydrogenation activity.

Table 5. Comparison of $\mathrm{Cu}$ based catalysts reported inthe literature and this work. 


\begin{tabular}{|c|c|c|c|c|c|}
\hline Catalyst & $\begin{array}{c}\text { Reaction } \\
\text { conditions }\end{array}$ & $\begin{array}{l}\text { Hydrogen } \\
\text { source \& } \\
\text { pressure }\end{array}$ & $\begin{array}{c}\text { LA } \\
\text { conversion } \\
(\%)\end{array}$ & $\begin{array}{c}\text { GVL } \\
\text { selectivity } \\
(\%)\end{array}$ & Reference \\
\hline $\mathrm{Cu} / \mathrm{SiO}_{2}-\mathrm{Q} 6$ & $\begin{array}{c}\mathrm{T}=250^{\circ} \mathrm{C}, \mathrm{m}= \\
0.75 \mathrm{~g}, \mathrm{LA}: \mathrm{FA}= \\
1: 2\end{array}$ & Formic acid & 66 & 81 & [20] \\
\hline $\mathrm{Cu}-\mathrm{Ni} / \mathrm{Al}-\mathrm{Fe}$ & $\begin{aligned} \mathrm{T}= & 150^{\circ} \mathrm{C}, \mathrm{m}= \\
& 0.125 \mathrm{~g}\end{aligned}$ & $\mathrm{H}_{2}$ & 95 & 70 & [18] \\
\hline $\begin{array}{l}\text { 8 wt. } \% \mathrm{Cu}-12 \\
\text { wt. } \% \mathrm{Co} / \mathrm{Al}_{2} \mathrm{O}_{3}\end{array}$ & $\begin{aligned} \mathrm{T}= & 250^{\circ} \mathrm{C}, \mathrm{m}= \\
& 0.250 \mathrm{~g}\end{aligned}$ & $\overline{\mathrm{H}_{2}}$ & 100 & 99 & [39] \\
\hline $20 \% \mathrm{Cu} / \mathrm{Al}_{2} \mathrm{O}_{3}$ & $\begin{array}{c}\mathrm{T}=240^{\circ} \mathrm{C}, \mathrm{m}=0.5 \\
\mathrm{~g}\end{array}$ & $\mathrm{H}_{2}$ & 93.7 & 91.5 & [22] \\
\hline $30 \% \mathrm{Cu}-\mathrm{ZrO}_{2}$ & $\begin{array}{c}\mathrm{T}=200^{\circ} \mathrm{C}, \mathrm{m}= \\
0.05 \mathrm{~g}\end{array}$ & $\mathrm{H}_{2}, 27 \mathrm{bar}$ & & 90 & [40] \\
\hline $\begin{array}{c}3 \text { wt. } \% \\
\mathrm{Cu} / \mathrm{Zr}_{0.8}-\mathrm{Ce}_{0.2}\end{array}$ & $\begin{array}{c}\mathrm{T}=260^{\circ} \mathrm{C}, \mathrm{m}=0.5 \\
\mathrm{~g}\end{array}$ & $\begin{array}{c}\text { Formic acid, } \\
0.5 \mathrm{Mpa}\end{array}$ & 88.5 & 94.2 & [41] \\
\hline $\begin{array}{c}\text { 3 wt.\% } \\
\mathrm{Cu} / \mathrm{HTC} *\end{array}$ & $\begin{array}{c}\mathrm{T}=265^{\circ} \mathrm{C}, \mathrm{m}=0.5 \\
\mathrm{~g}\end{array}$ & $\mathrm{H}_{2}$ & 87.5 & 95 & [42] \\
\hline $\begin{array}{c}4.7 \text { wt. } \% \\
\mathrm{Cu} / \mathrm{ZrO}_{2}-\mathrm{Al}_{2} \mathrm{O}_{3} \\
\end{array}$ & $\begin{array}{c}\mathrm{T}=130^{\circ} \mathrm{C}, \mathrm{m}=0.5 \\
\mathrm{~g}\end{array}$ & $\mathrm{H}_{2}, 3.0 \mathrm{MPa}$ & 100 & 100 & [43] \\
\hline $\begin{array}{c}3 \text { wt.\% B } 18 \\
\text { wt. } \% \mathrm{Cu} / \mathrm{ZrO}_{2}\end{array}$ & $\mathrm{~T}=150^{\circ} \mathrm{C}, \mathrm{m}=0.2$ & $\mathrm{H}_{2}, 3.0 \mathrm{MPa}$ & 100 & 100 & [38] \\
\hline $\begin{array}{c}32.3 \mathrm{wt} \% \\
\mathrm{Cu} / 5 \% \mathrm{Al}_{2} \mathrm{O}_{3^{-}} \\
\mathrm{ZrO}_{2} \\
\end{array}$ & $\begin{array}{c}\mathrm{T}=200^{\circ} \mathrm{C}, \mathrm{m}= \\
0.05 \mathrm{~g}\end{array}$ & $\mathrm{H}_{2}, 3.0 \mathrm{MPa}$ & 100 & 100 & [44] \\
\hline $\begin{array}{c}5 \text { wt. } \% \mathrm{Cu} / \mathrm{SBA}- \\
15 \\
\end{array}$ & $\begin{array}{c}\mathrm{T}=265^{\circ} \mathrm{C}, \mathrm{m}=0.3 \\
\mathrm{~g}\end{array}$ & $\mathrm{H}_{2}, 0.1 \mathrm{MPa}$ & 100 & 98 & This work \\
\hline
\end{tabular}

*HTC = hydrotalcite;

In addition, further experiments were carried outto evaluate the stability of mesoporous silica-supported copper catalysts under time on stream of $50 \mathrm{~h}$ (Fig.9). Cu/SBA-15 was observed to be more stable with a complete LA conversion with negligible signs of deactivation during $30 \mathrm{~h}$ time on stream. For the $\mathrm{Cu} / \mathrm{MCM}-41$ catalyst, the LA conversion and selectivity was observed to be $85 \%$ and $77 \%$, respectively, during $15 \mathrm{~h}$ reaction time. However, a drastic decrease in LA conversion (51\%) and a slight decrease in GVL selectivity was observed as the TOS reached $50 \mathrm{~h}$. For the Cu/MCM-48 catalyst, the conversion of LA decreased linearly with time for the first $20 \mathrm{~h}$ approaching $87 \%$ conversion, however, the activity decreased to $53 \%$ whenfurther increasing time on stream. The reason behind the activity loss can be ascribed to the possible catalyst deactivation due to the blockage of the catalyst pores. Furthermore, for $\mathrm{CU} / \mathrm{KIT}-6$, the LA conversion and GVL selectivity decreased rapidly during the initial $20 \mathrm{~h}$ under stream and attained only $40-50 \%$ conversion revealing continuous deactivation during the reaction time. Thus, stability studies of catalysts suggested that $\mathrm{Cu} / \mathrm{SBA}-15$ exhibited higher stability compared to $\mathrm{Cu} / \mathrm{MCM}-$ 41, $\mathrm{Cu} / \mathrm{MCM}-48$, and $\mathrm{Cu} / \mathrm{KIT}-6$ catalysts.

\section{Conclusions}


Vapor-phase hydrogenation of LA to GVL was carried out in afixed-bed reactor over different mesoporous silica-supported copper catalysts at ambient hydrogen pressure. From characterisation results, the diffraction patterns and $\mathrm{N}_{2}$ adsorption-desorption studies revealed that the $\mathrm{Cu}$ impregnated catalysts retained their mesoporosity and the support structure was intact. Moreover, XRD results showed the presence of a highly dispersed $\mathrm{CuO}$ species over all the catalysts except $\mathrm{Cu} / \mathrm{KIT}-6$. The support structure had a profound effect on the activity of the catalyst. The copper modified SBA-15 and MCM-48 had desired properties and presented better performance compared to other catalysts. Overall, the Cu-SBA-15 catalyst exhibited the highest catalytic activity in terms of LA conversion $(100 \%)$ and GVL selectivity (98\%) compared to other prepared catalysts due to its high surface acidity and Cu dispersion. The study further indicated that the copper surface area, acidity and diffusion limitation of reactants into pore channels were the key factors, which influenced the activity of catalysts. The overall activity trend of different mesoporous silica-supported copper catalysts for the LA conversion was found as Cu-SBA15>Cu-MCM-48>Cu-MCM-41>Cu-KIT-6.

\section{Declarations}

\section{Acknowledgments \& funding}

Dr. Putra Kumaracknowledgesthe Council of Scientific and Industrial Research (CSIR), New Delhi for the award of Senior Research Fellowship (SRF). Dr. Putra Kumar acknowledges funding provided by National Science Foundation of China (Project No.51871114) to carry out the research.

\section{Conflicts of interest/Competing interests}

There is no conflict of interest (not applicable).

\section{References}

1. Climent MJ, Corma A, Iborra S (2014) Conversion of biomass platform molecules into fuel additives and liquid hydrocarbon fuels. Green Chem 14:516-547. doi: 10.1039/c3gc41492b

2. Wenxiu Cao, Wenhao Luo, Hongguang Ge, Yang Su, Aiqin Wang and TZ (2017) UiO-66 derived Ru/ZrO2@C as a highly stable catalyst for hydrogenation of levulinic acid to $\gamma$-valerolactone. Green Chem 19:2201-2211. doi: 10.1039/C7GC00512A

3. Yang Y, Sun C, Brown DE, Zhang L, Yang F (2016) A smart strategy to fabricate Ru nanoparticle inserted porous carbon nano $\mathrm{fi}$ bers as highly e ffi cient levulinic acid hydrogenation catalysts $\mathrm{t}$. Green Chem 18:3558-3566. doi: 10.1039/c5gc02802g

4. Touchy AS, Hakim Siddiki SMA, Kon K, Shimizu KI (2014) Heterogeneous Pt catalysts for reductive amination of levulinic acid to pyrrolidones. ACS Catal 4:3045-3050. doi: 10.1021/cs500757k 
5. Yan K, Jarvis C, Gu J, Yan Y (2015) Production and catalytic transformation of levulinic acid: A platform for speciality chemicals and fuels. Renew Sustain Energy Rev 51:986-997. doi:

10.1016/j.rser.2015.07.021

6. Yan K, Yang Y, Chai J, Lu Y (2015) Catalytic reactions of gamma-valerolactone: A platform to fuels and value-added chemicals. Appl Catal B Environ 179:292-304. doi: 10.1016/j.apcatb.2015.04.030

7. Dhanalaxmi K, Singuru R, Mondal S, Bai L, Reddy BM, Bhaumik A, Mondal J (2017) Magnetic Nanohybrid Decorated Porous Organic Polymer: Synergistic Catalyst for High Performance Levulinic Acid Hydrogenation. ACS Sustain Chem Eng 5:1033-1045. doi: 10.1021/acssuschemeng.6b02338

8. Gu XM, Zhang B, Liang HJ, Ge H Bin, Yang HM, Qin Y (2017) Pt/HZSM-5 catalyst synthesized by atomic layer deposition for aqueous-phase hydrogenation of levulinic acid to valeric acid. Ranliao Huaxue Xuebao/Journal Fuel Chem Technol 45:714-722. doi: 10.1016/s1872-5813(17)30035-x

9. Mustafin K, Cárdenas-Lizana F, Keane MA (2017) Continuous gas phase catalytic transformation of levulinic acid to $Y$-valerolactone over supported Au catalysts. J Chem Technol Biotechnol 92:2221-2228. doi: $10.1002 /$ jctb. 5258

10. Piskun AS, De Haan JE, Wilbers E, Van De Bovenkamp HH, Tang Z, Heeres HJ (2016) Hydrogenation of Levulinic Acid to Y-Valerolactone in Water Using Millimeter Sized Supported Ru Catalysts in a Packed Bed Reactor. ACS Sustain Chem Eng 4:2939-2950. doi: 10.1021/acssuschemeng.5b00774

11. Yan K, Lafleur T, Jarvis C, Wu G (2014) Clean and selective production of $\mathrm{Y}$-valerolactone from biomass-derived levulinic acid catalyzed by recyclable Pd nanoparticle catalyst. J Clean Prod 72:230232. doi: $10.1016 /$ j.jclepro.2014.02.056

12. Song S, Yao S, Cao J, Di L, Wu G, Guan N, Li L (2017) Heterostructured Ni/NiO composite as a robust catalyst for the hydrogenation of levulinic acid to $\gamma$-valerolactone. Appl Catal B Environ 217:115124. doi: 10.1016/j.apcatb.2017.05.073

13. Sun P, Gao G, Zhao Z, Xia C, Li F (2014) Stabilization of cobalt catalysts by embedment for efficient production of valeric biofuel. ACS Catal 4:4136-4142. doi: 10.1021/cs501409s

14. Yuan J, Li SS, Yu L, Liu YM, Cao Y, He HY, Fan KN (2013) Copper-based catalysts for the efficient conversion of carbohydrate biomass into $\mathrm{Y}$-valerolactone in the absence of externally added hydrogen. Energy Environ Sci 6:3308-3313. doi: 10.1039/c3ee40857d

15. Wettstein SG, Bond JQ, Alonso DM, Pham HN, Datye AK, Dumesic JA (2012) RuSn bimetallic catalysts for selective hydrogenation of levulinic acid to $Y$-valerolactone. Appl Catal B Environ 117118:321-329. doi: 10.1016/j.apcatb.2012.01.033

16. Yan K, Chen A (2014) Selective hydrogenation of furfural and levulinic acid to biofuels on the ecofriendly Cu-Fe catalyst. Fuel 115:101-108. doi: 10.1016/j.fuel.2013.06.042 
17. Yang Y, Gao G, Zhang X, Li F (2014) Facile fabrication of composition-tuned Ru-Ni bimetallics in ordered mesoporous carbon for levulinic acid hydrogenation. ACS Catal 4:1419-1425. doi:

$10.1021 / \operatorname{cs} 401030 u$

18. Zhang R, Ma Y, You F, Peng T, He Z, Li K (2017) Exploring to direct the reaction pathway for hydrogenation of levulinic acid into $\Gamma$-valerolactone for future Clean-Energy Vehicles over a magnetic $\mathrm{Cu}$ Ni catalyst. Int J Hydrogen Energy 42:25185-25194. doi: 10.1016/j.ijhydene.2017.08.121

19. Upare PP, Lee JM, Hwang YK, Hwang DW, Lee JH, Halligudi SB, Hwang JS, Chang JS (2011) Direct hydrocyclization of biomass-derived levulinic acid to 2-methyltetrahydrofuran over nanocomposite copper/silica catalysts. ChemSusChem 4:1749-1752. doi: 10.1002/cssc.201100380

20. Lomate S, Sultana A, Fujitani T (2017) Effect of SiO2 support properties on the performance of Cu$\mathrm{SiO} 2$ catalysts for the hydrogenation of levulinic acid to gamma valerolactone using formic acid as a hydrogen source. Catal Sci Technol 7:3073-3083. doi: 10.1039/c7cy00902j

21. Yoshida R, Sun D, Yamada Y, Sato S, Hutchings GJ (2017) Vapor-phase hydrogenation of levulinic acid to $\Gamma$-valerolactone over Cu-Ni bimetallic catalysts. Catal Commun 97:79-82. doi: 10.1016/j.catcom.2017.04.018

22. Sun D, Ohkubo A, Asami K, Katori T, Yamada Y, Sato S (2017) Vapor-phase hydrogenation of levulinic acid and methyl levulinate to $\Gamma$-valerolactone over non-noble metal-based catalysts. Mol Catal 437:105-113. doi: 10.1016/j.mcat.2017.05.009

23. Balla P, Perupogu V, Vanama PK, Komandur VRC (2016) Hydrogenation of biomass-derived levulinic acid to $\mathrm{Y}$-valerolactone over copper catalysts supported on ZrO2. J Chem Technol Biotechnol 91:769776. doi: $10.1002 /$ jctb. 4643

24. Putrakumar B, Nagaraju N, Kumar VP, Chary KVR (2015) Hydrogenation of levulinic acid to $Y^{-}$ valerolactone over copper catalysts supported on Y-Al203. Catal Today 250:209-217. doi: 10.1016/j.cattod.2014.07.014

25. Hoffmann F, Cornelius M, Morell J, Fröba M (2006) Silica-based mesoporous organic-inorganic hybrid materials. Angew Chemie - Int Ed 45:3216-3251. doi: 10.1002/anie.200503075

26. Patel A, Shukla P, Rufford T, Wang S, Chen J, Rudolph V, Zhu Z (2011) Catalytic reduction of NO by CO over copper-oxide supported mesoporous silica. Appl Catal A Gen 409-410:55-65. doi:

10.1016/j.apcata.2011.09.024

27. Fulvio PF, Pikus S, Jaroniec M (2010) SBA-15-supported mixed-metal oxides: Partial hydrolytic solgel synthesis, adsorption, and structural properties. ACS Appl Mater Interfaces 2:134-142. doi: $10.1021 / \mathrm{am} 900625 \mathrm{c}$ 
28. Abrokwah RY, Deshmane VG, Kuila D (2016) Comparative performance of M-MCM-41 (M: Cu, Co, Ni, $\mathrm{Pd}, \mathrm{Zn}$ and $\mathrm{Sn}$ ) catalysts for steam reforming of methanol. J Mol Catal A Chem 425:10-20. doi: 10.1016/j.molcata.2016.09.019

29. Zhao Q, Shen Y, Wang Q, Tian J, Zhou X, Jiang T (2013) A comparative investigation on the catalytic activity of H-Al-MCM-48 and H-Zr-MCM-48 mesoporous molecular sieve on alkylation of phenol with tert-butyl alcohol. Chem Eng J 230:124-132. doi: 10.1016/j.cej.2013.06.057

30. Prabhu A, Kumaresan L, Palanichamy M, Murugesan V (2009) Synthesis and characterization of aluminium incorporated mesoporous KIT-6: Efficient catalyst for acylation of phenol. Appl Catal A Gen 360:59-65. doi: 10.1016/j.apcata.2009.03.004

31. Frey AS, Hinrichsen $\mathrm{O}$ (2012) Comparison of differently synthesized Ni(Al)MCM-48 catalysts in the ethene to propene reaction. Microporous Mesoporous Mater 164:164-171. doi:

10.1016/j.micromeso.2012.07.015

32. Tüysüz H, Lehmann CW, Bongard H, Tesche B, Schmidt R, Schüth F (2008) Direct imaging of surface topology and pore system of ordered mesoporous silica (MCM-41, SBA-15, and KIT-6) and nanocast metal oxides by high resolution scanning electron microscopy. J Am Chem Soc 130:11510-11517. doi: $10.1021 /$ ja803362s

33. Derrien G, Charnay C, Zajac J, Jones DJ, Rozière J (2008) Copper-containing monodisperse mesoporous silica nanospheres by a smart one-step approach. Chem Commun 3118-3120. doi: $10.1039 / \mathrm{b} 804593 \mathrm{c}$

34. Chmielarz L, Kuśtrowski P, Dziembaj R, Cool P, Vansant EF (2006) Catalytic performance of various mesoporous silicas modified with copper or iron oxides introduced by different ways in the selective reduction of NO by ammonia. Appl Catal B Environ 62:369-380. doi: 10.1016/j.apcatb.2005.09.004

35. Chary KVR, Sagar GV, Naresh D, Seela KK, Sridhar B (2005) Characterization and reactivity of copper oxide catalysts supported on TiO2-ZrO2. J Phys Chem B 109:9437-9444. doi: 10.1021/jp0500135

36. Sagar GV, Rao PVR, Srikanth CS, Chary KVR (2006) Dispersion and reactivity of copper catalysts supported on Al 203-ZrO2. J Phys Chem B 110:13881-13888. doi: 10.1021/jp0575153

37. Subbaramaiah V, Srivastava VC, Mall ID (2013) Optimization of reaction parameters and kinetic modeling of catalytic wet peroxidation of picoline by Cu/SBA-15. Ind Eng Chem Res 52:9021-9029. doi: 10.1021/ie400124d

38. Li JF, Zhao L, Li J, Li M, Liu CL, Yang RZ, Dong WS (2019) Highly selective synthesis of Yvalerolactone from levulinic acid at mild conditions catalyzed by boron oxide doped $\mathrm{Cu} / \mathrm{ZrO} 2$ catalysts. Appl Catal A Gen 587:117244. doi: 10.1016/j.apcata.2019.117244 
39. Yanase D, Yoshida R, Kanazawa S, Yamada Y, Sato S (2020) Efficient formation of $Y$-valerolactone in the vapor-phase hydrogenation of levulinic acid over $\mathrm{Cu}-\mathrm{Co} /$ alumina catalyst. Catal Commun 139:105967. doi: 10.1016/j.catcom.2020.105967

40. Orlowski I, Douthwaite M, Iqbal S, Hayward JS, Davies TE, Bartley JK, Miedziak PJ, Hirayama J, Morgan DJ, Willock DJ, Hutchings GJ (2019) The hydrogenation of levulinic acid to $\Gamma$-valerolactone over $\mathrm{Cu}-\mathrm{ZrO} 2$ catalysts prepared by a pH-gradient methodology. J Energy Chem 36:15-24. doi:

10.1016/j.jechem.2019.01.015

41. Mitta H, Perupogu V, Boddula R, Ginjupalli SR, Inamuddin, Asiri AM (2020) Enhanced production of $\mathrm{Y}$-valerolactone from levulinic acid hydrogenation-cyclization over ZrxCe1-xO2 based Cu catalysts. Int $\mathrm{J}$ Hydrogen Energy 45:26445-26457. doi: 10.1016/j.ijhydene.2019.11.149

42. Mitta H, Seelam PK, Chary KVR, Mutyala S, Boddula R, Inamuddin, Asiri AM (2018) Efficient VaporPhase Selective Hydrogenolysis of Bio-Levulinic Acid to $Y$-Valerolactone Using Cu Supported on Hydrotalcite Catalysts. Glob Challenges 2:1800028. doi: 10.1002/gch2.201800028

43. Li J, Li M, Zhang C, Liu CL, Yang RZ, Dong WS (2020) Construction of mesoporous Cu/ZrO2-Al2O3 as a ternary catalyst for efficient synthesis of $\mathrm{y}$-valerolactone from levulinic acid at low temperature. $\mathrm{J}$ Catal 381:163-174. doi: 10.1016/j.jcat.2019.10.031

44. He D, He Q, Jiang P, Zhou G, Hu R, Fu W (2019) Novel Cu/Al2O3-ZrO2 composite for selective hydrogenation of levulinic acid to $\Gamma$-valerolactone. Catal Commun 125:82-86. doi:

10.1016/j.catcom.2019.03.029

\section{Figures}
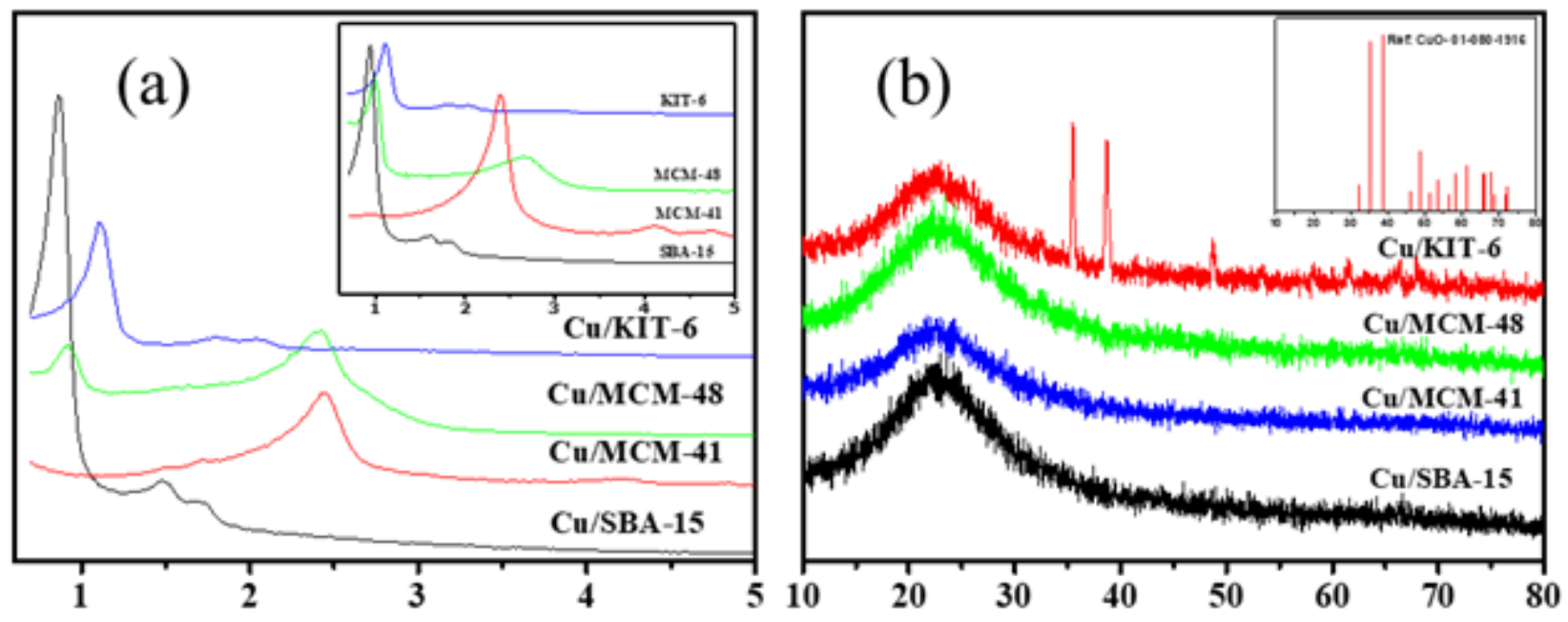

Figure 1 
Low angle XRD patternsof various (a) mesoporous silica supported copper catalysts and (inset Figure 1a) parent mesoporous silica and (b)wide angle XRD pattersof various mesoporous silica supported copper catalysts.
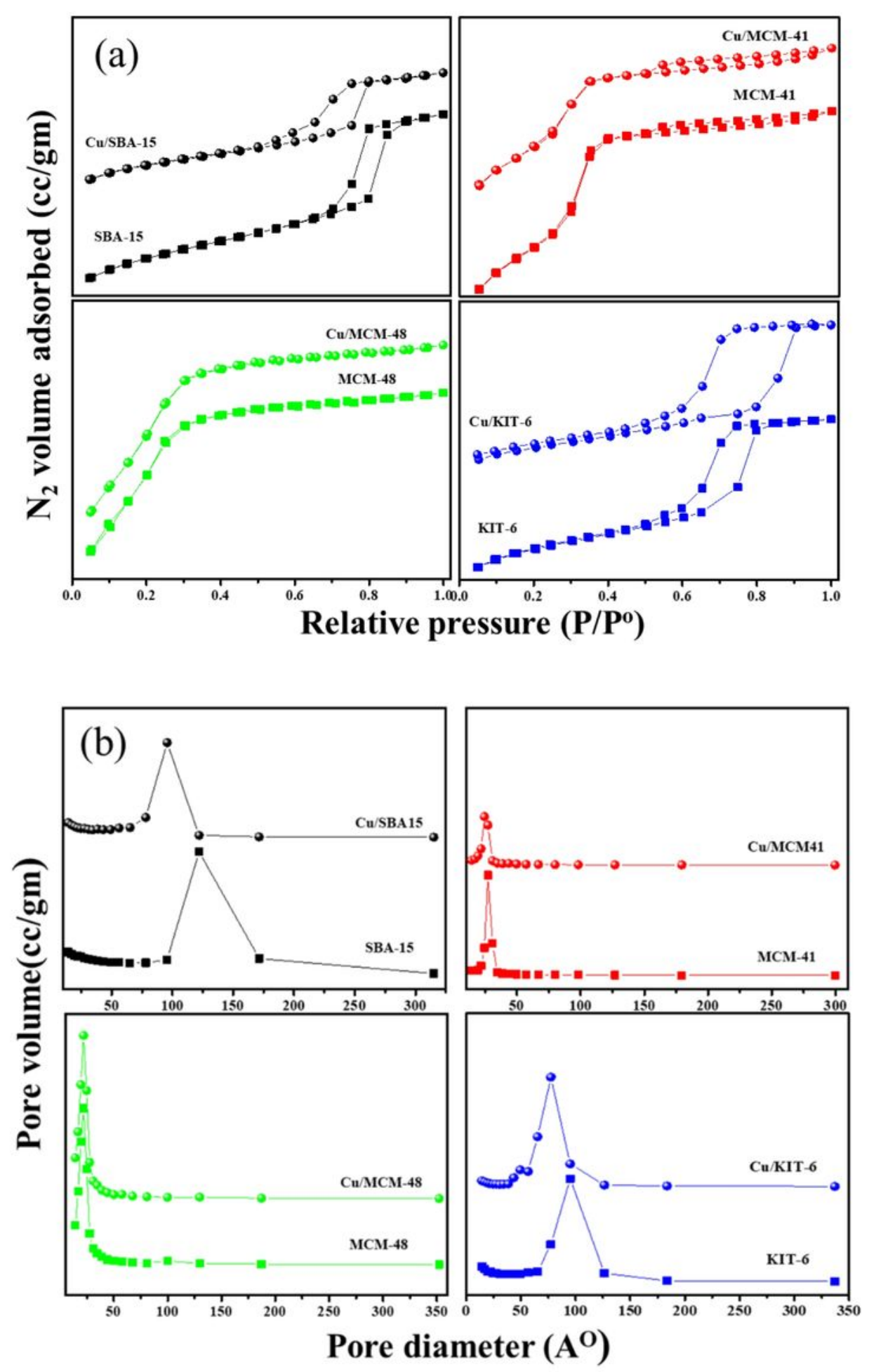

Figure 2

(a) Nitrogen sorption isotherms and the (b) BJH pore size distribution of mesoporous silica supports and the copper supported silica basedcatalysts. 


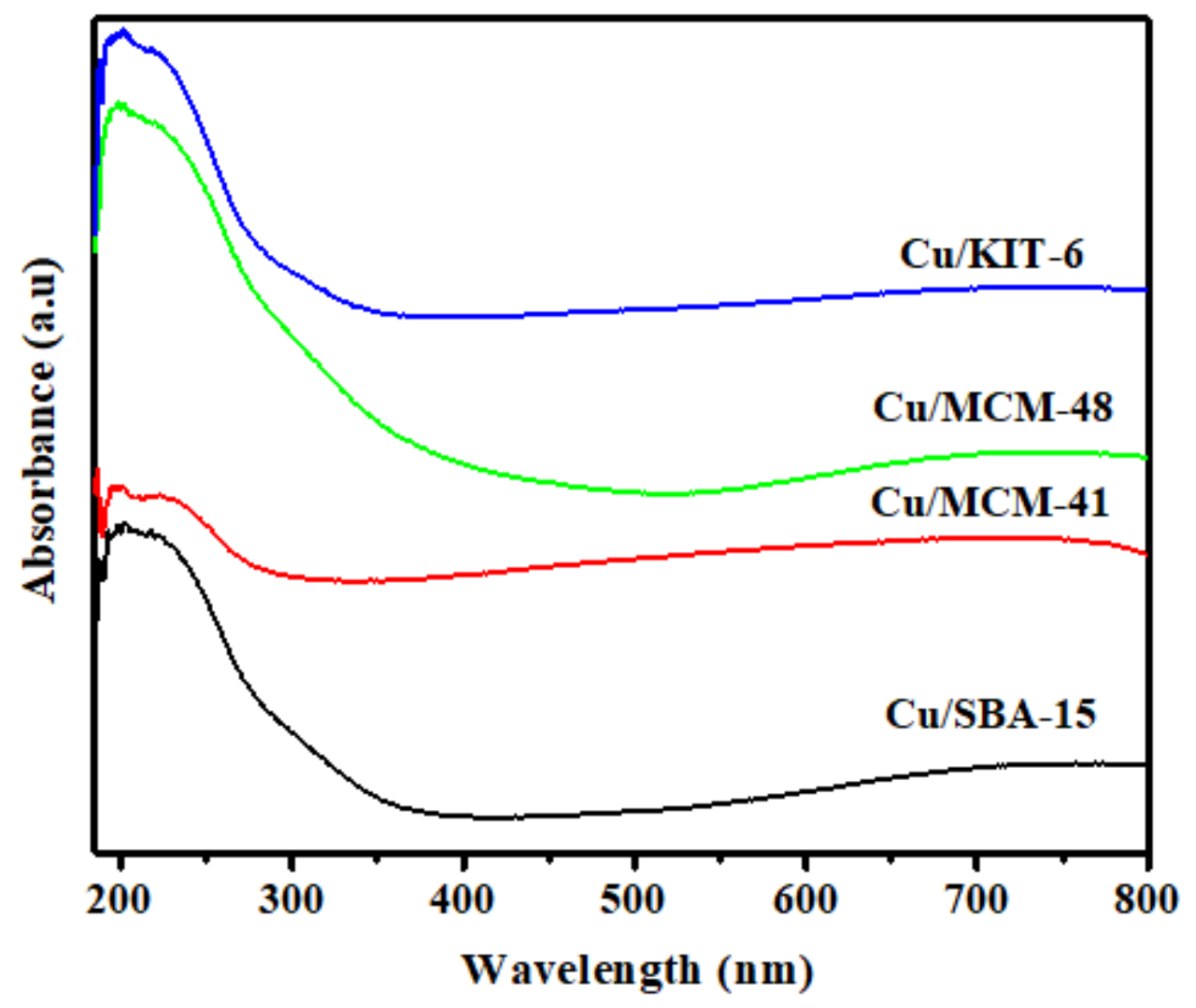

Figure 3

UV-DRS spectra of CuO supported on mesoporous silica catalysts. 


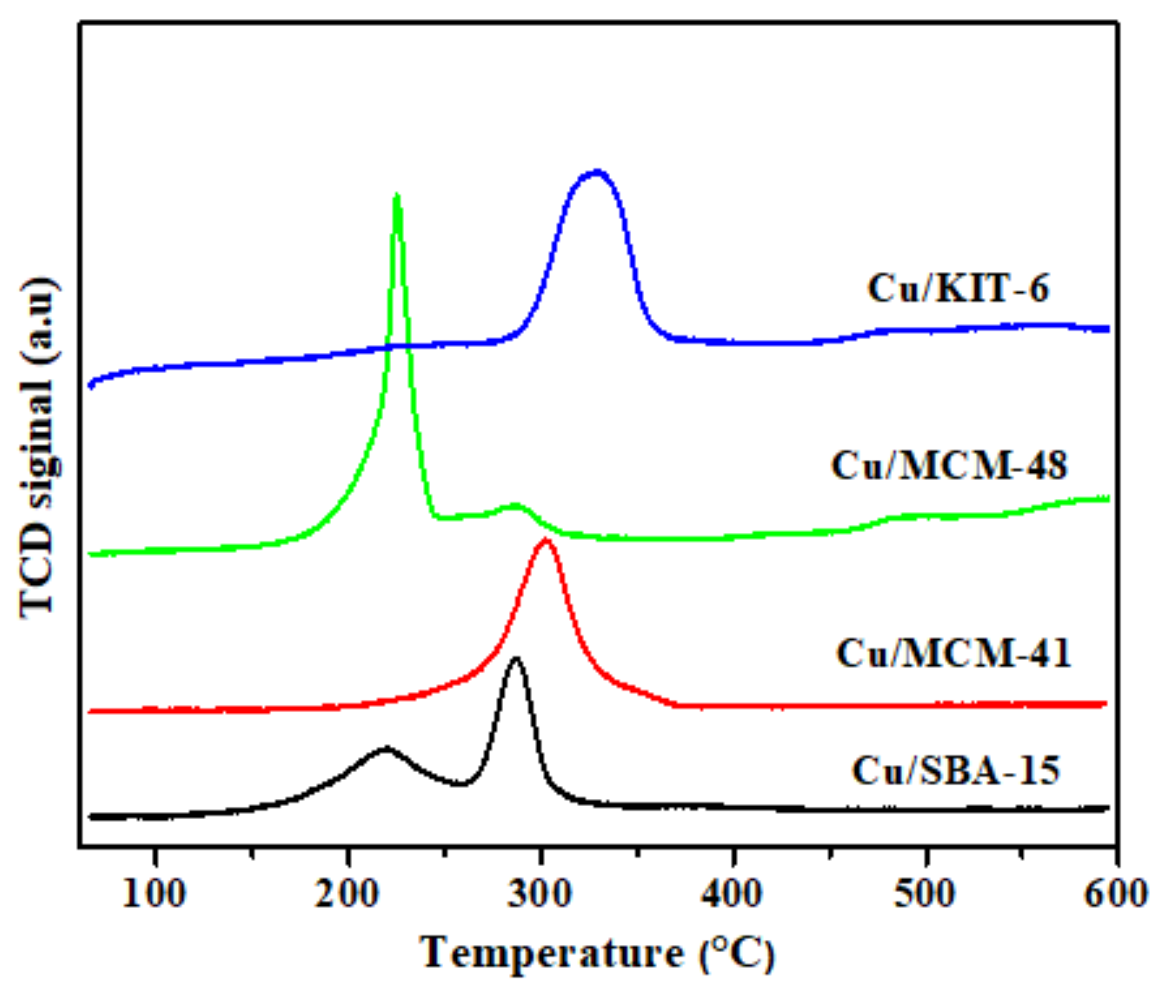

Figure 4

TPR profiles of $\mathrm{CuO}$ supported on mesoporous silica catalysts.

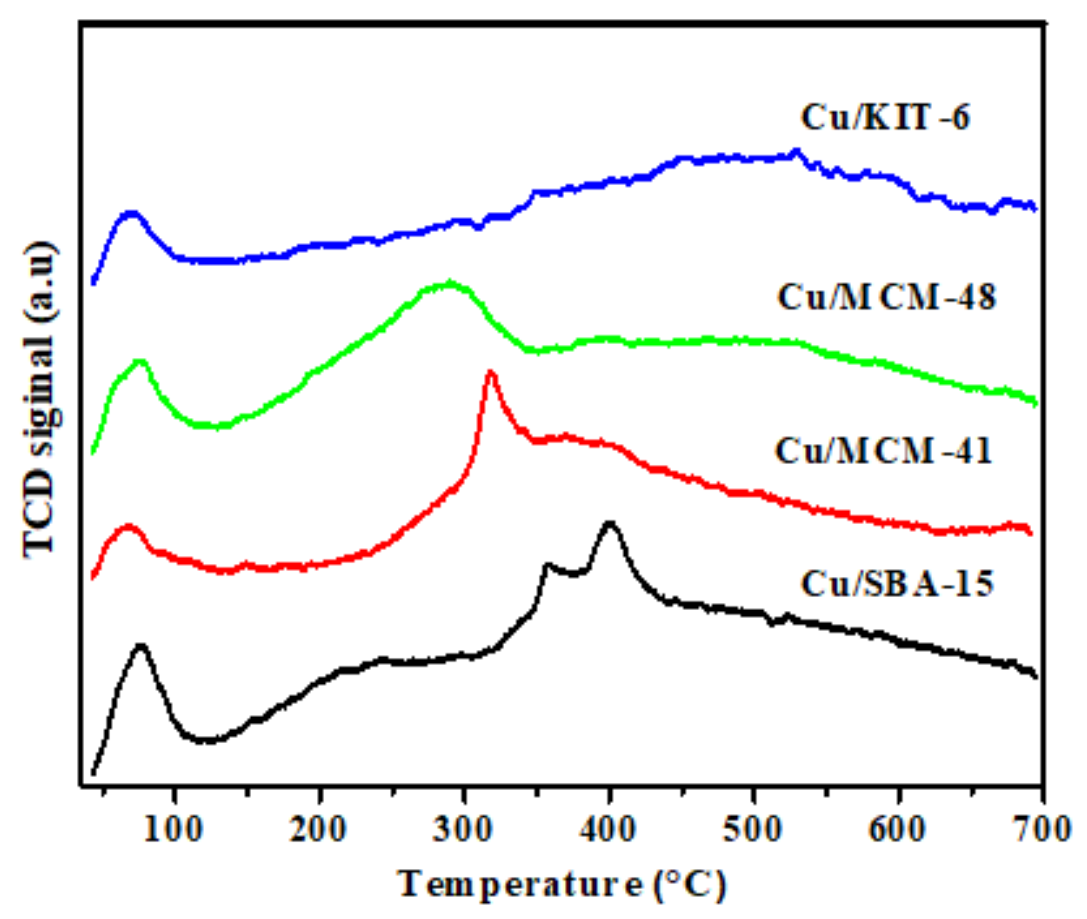

Figure 5 
NH3-TPD profiles of CuO supported on mesoporous silicas catalysts.
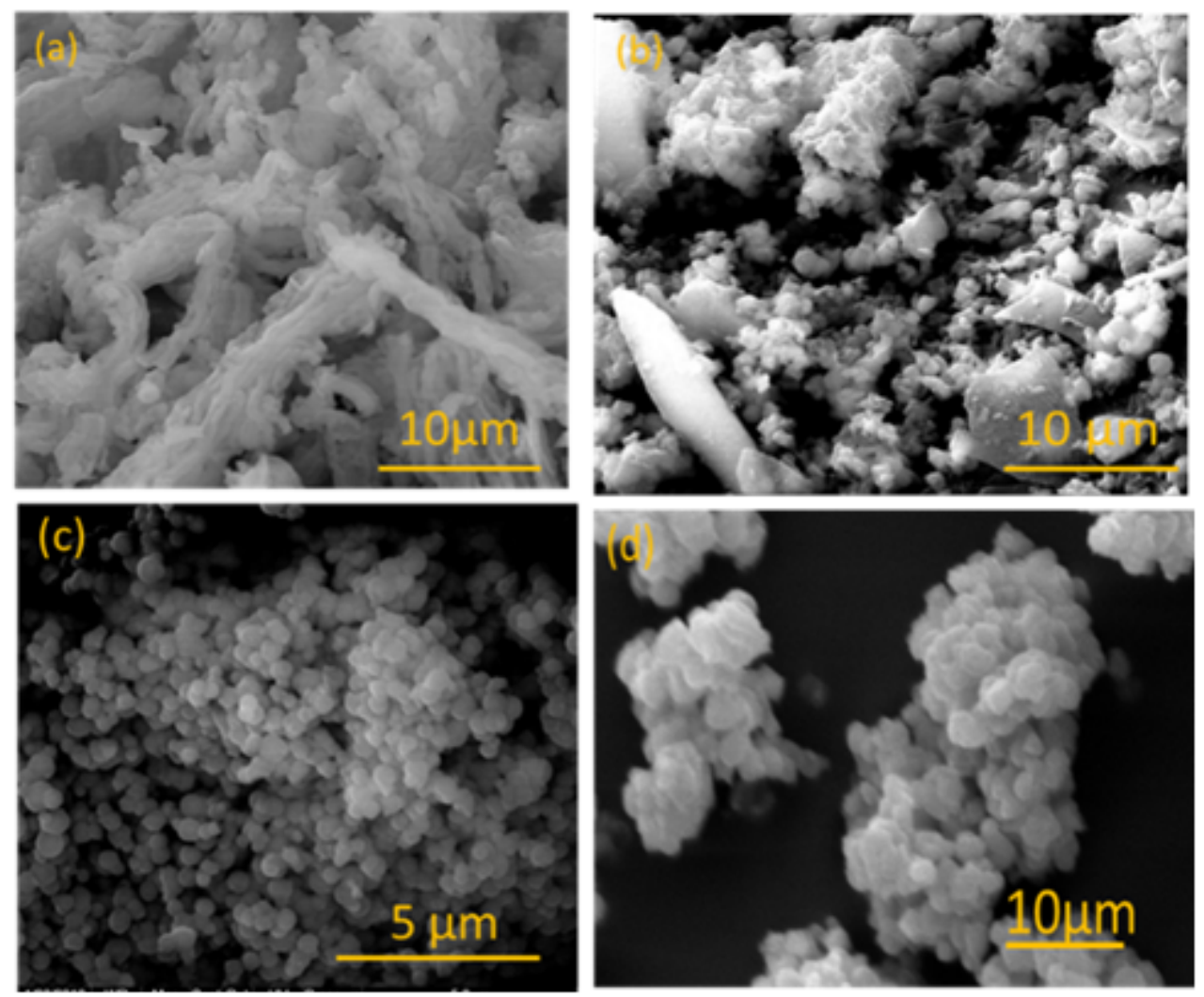

\section{Figure 6}

SEM images of (a) Cu/SBA-15 (b) Cu/MCM-41 (c) Cu/MCM-48 (d) Cu/KIT-6 catalysts. 

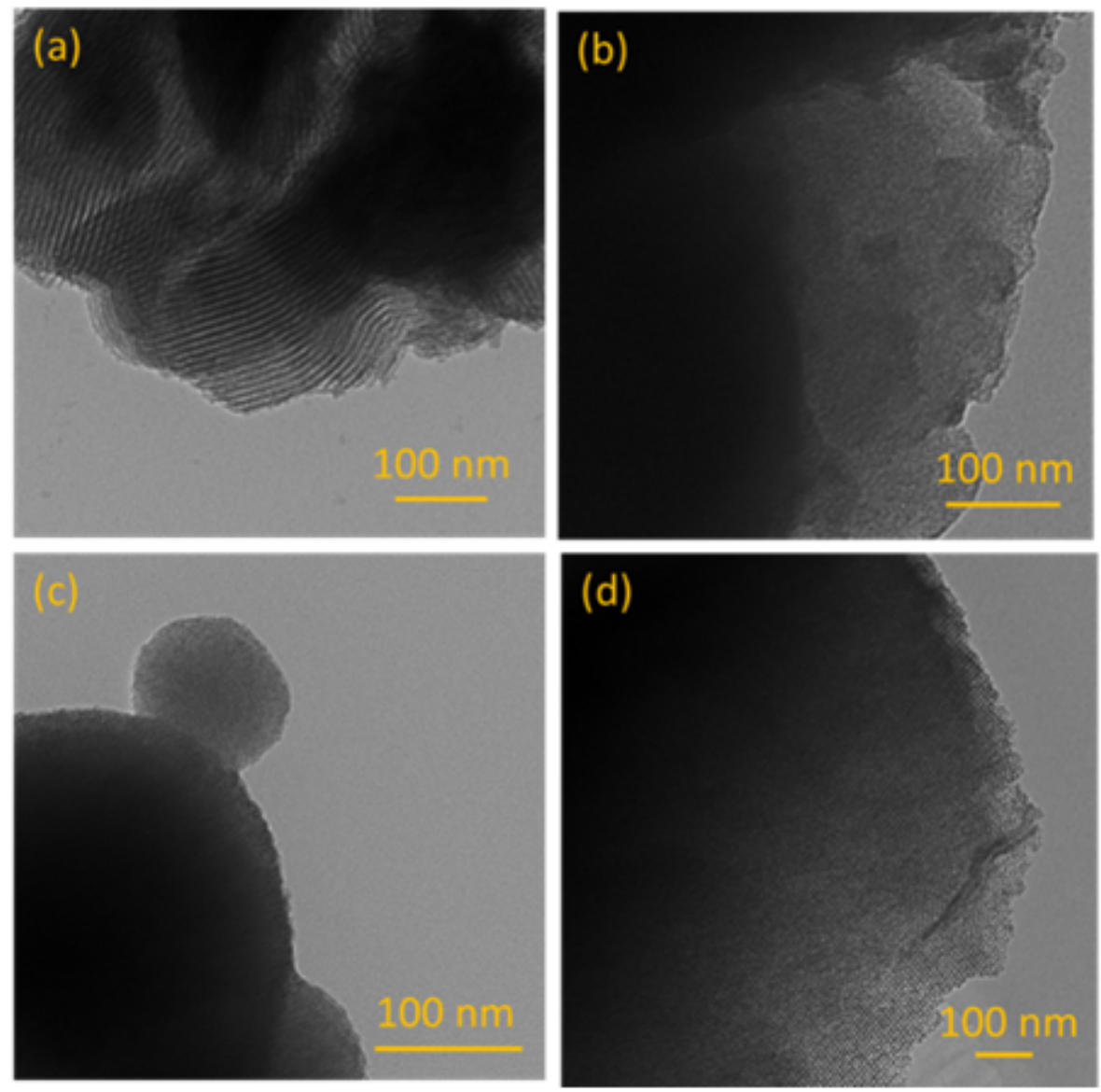

Figure 7

TEM images of (a) Cu/SBA-15 (b) Cu/MCM-41 (c) Cu/MCM-48 (d) Cu/KIT-6 catalysts 


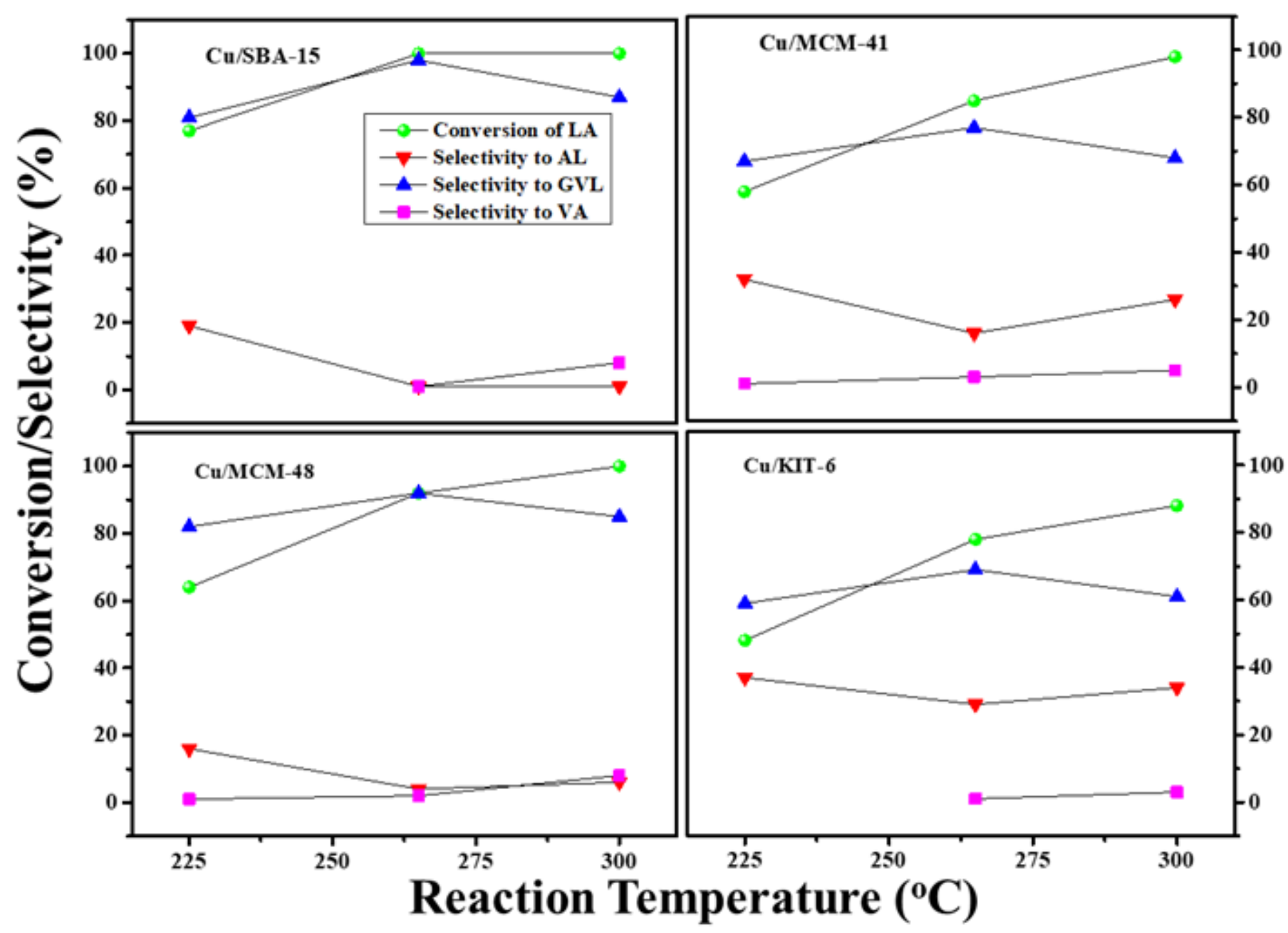

Figure 8

Effect of reaction temperature versus activity in LA conversion and selectivity over the various mesoporous silica supported copper catalysts. 


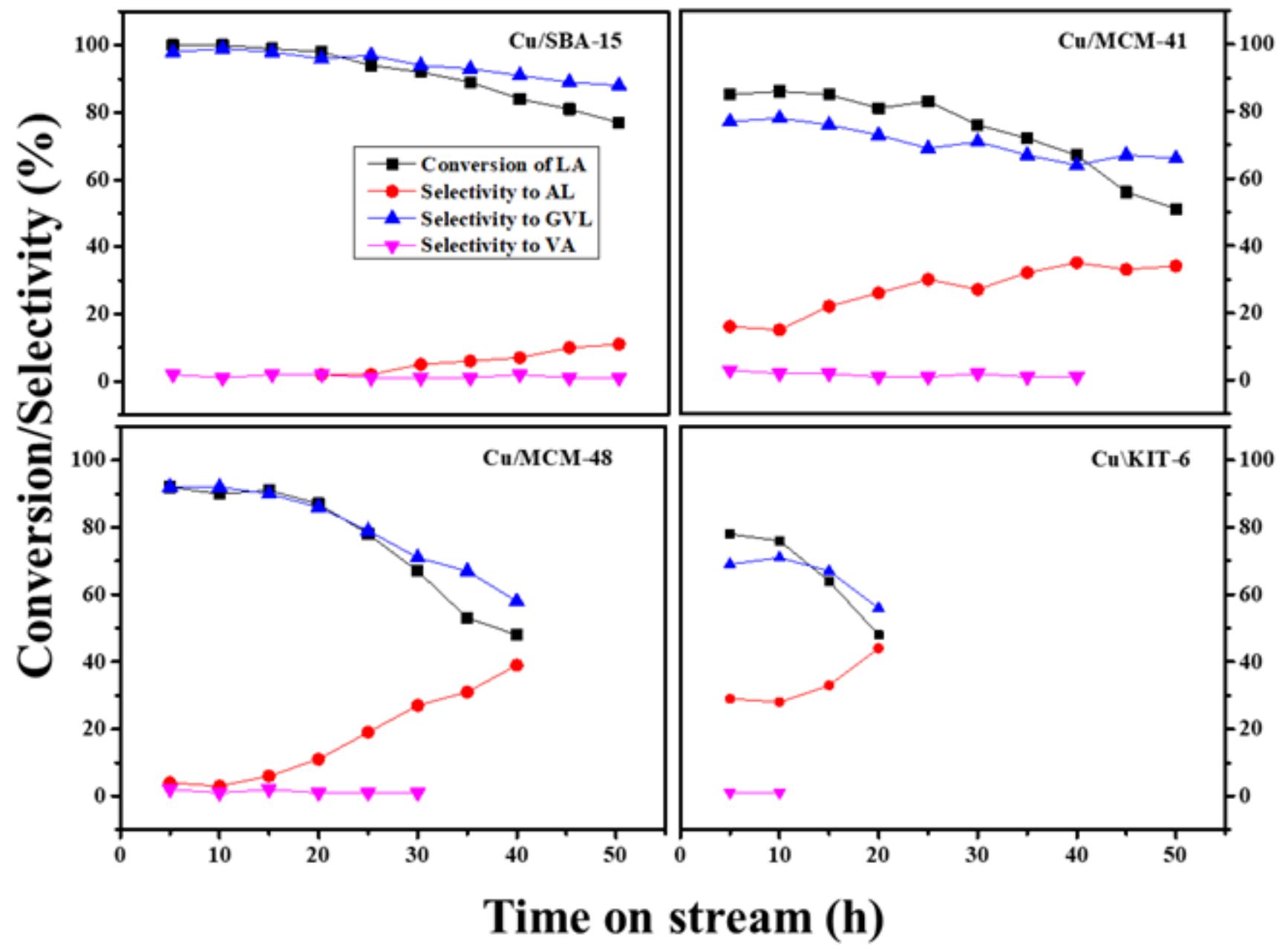

Figure 9

Time on stream studies of various mesoporous silica supported copper catalysts.

\section{Supplementary Files}

This is a list of supplementary files associated with this preprint. Click to download.

- Graphicalabstract.tif 